Результати дослідження. Диджиталізація в умовах сучасної економіки є одним із головних інструментів розвитку підприємств, спрямованих на успішне ведення усіх бізнес-прочесів. Завдяки диджиталізації з'являється можливість спростити та здійснювати роботу в більш швидкому темпі, використовуючи великі бази даних, забезпечуючи автоматизачію всіх видів діяльності, як основної, так інвестиційної та фінансової, покращити комунікацію між клієнтами, постачальниками та партнерами, збільшити мобільність у взаємодії у межах підприємства - між підрозділами, прачівниками, менеджментом, здійснити перехід до таких нових організачійних форм господарювання, як мережева чи віртуальна економіка.

Висновки. Світова економічна криза, спричинена пандемією COVID-19, вимагає від суб'єктів малого та середнього бізнесу адаптациї до різновекторних пріоритетів, серед яких у короткостроковій перспективі домінуватимуть такі тендениіі розвитку: інтернаціоналізація, локалізація та використання диджитал-платформ.

Ключові слова: диджиталізація, диджитал-технології, диджитал-економіка, диджитал-платформи, бізнес-процеси, малий та середній бізнес.

UDC 453.87.35

JEL Classification: F23, O15

DOI: http://doi.org/10.31617/visnik.knute.2020(134)04

BUSARIEVA Tatiana,

$\mathrm{PhD}$ (Economics), Associate Professor,

doctoral student of the World Economy Department

of Kyiv National University of Trade and Economics

19, Kyoto str., Kyiv, 02156, Ukraine

E-mail:sutner@ukr.net

ORCID: 0000-0001-9563-8120

\title{
THE UNIVERSAL MODEL OF KNOWLEDGE MANAGEMENT OF CORPORATIONS
}

The components of the universal model of knowledge management of TNCs are considered and human, structural, innovative capital and capital of relations are characterized. Measurements of intellectual capital and sources of its quantitative assessment in the context of knowledge management are analyzed. It is proved that in the conditions of the formation of the knowledge economy and limited resources, the possibility of introducing a knowledge management system in an organization is its main competitive advantage. The role of the knowledge management model in ensuring the effectiveness of TNCs is established.

Keywords: knowledge economy, TNC, knowledge management, resource management, R\&D, knowledge management model.

(C) Busarieva T., 2020 
Background. In a knowledge-based economy, knowledge-based assets are becoming a key factor in the development of transnational corporations (TNCs). Accordingly, the company's ability to manage its intellectual capital is one of the defining competencies, which allows it to increase value for business owners. Thus, the prospects for the development of TNCs in the knowledge economy largely depend on its ability to manage intellectual capital. Due to the fact that the share of tangible assets in the market capitalization of companies in developed markets by early 2010 decreased to $16 \%$ (in the late 2000s it was $52 \%$ ), the relevance of the study of intellectual capital as a key factor in the success of TNCs will only grow. It is obvious that in different industries the degree of influence of certain elements of intellectual capital on the performance of TNCs will be different, because even in developed markets, intellectual capital can play a different role in the activities of corporations. That is why in the development of the knowledge economy a necessary condition for the development of TNCs is the justification of the components of the universal model of knowledge management.

An analysis of recent researches and publications has shown that in multinational companies, the knowledge management system is an important asset that combines databases, documents, policies, procedures, previously unexplored knowledge and experience of individual employees. This approach ensures sustainable socio-economic development and forms the competitiveness of TNCs.

Given the limited resources, the ability to implement a knowledge management system in any multinational company is its main competitive advantage. Among scientific researches in the field of knowledge management by Ukrainian and foreign scientists a number of theoretical, methodological and methodical approaches to realization of process of knowledge management, various principles and methods of management, models of knowledge management are developed. I. Nonaka and X. Takeuchi [1], B. Milner, P. Senge, V. Bukovich, K. Viig, D.Ye. O'Leary, D. Snowden, Y. Vovk, M. Martynenko, A. Degtyar and M. Bubliy, A. Nalyvayko, N. Butenko, N. Smolinska and I. Hrybyk, S. Leonova and other scientists.

Thus, interesting research is made by B. Milner concerning the influence of knowledge management system on the functioning and development of the organizations [2]; scientific works of T. Gavrilove about the set of methodological approaches, procedures, technologies and mechanisms that allow the management of the organization tocreate additional value through the use of knowledge [3]; E. Popov as for formation of knowledge management institutions [4]; A. Tiwana offers knowledge management toolkit: practical techniques for building a knowledge management system [5]. At the same time, it is important to note that at the beginning of the XXI century in the conditions of knowledge economy development it is actual to provide management efficiency of TNCs intellectual resources. There are significant contributions in existing developments of the chosen field of re- 
search, although it should be noted another aspect that must be taken into account in the formation of the knowledge management system for TNCs. This identifies the components of a universal model for transnational corporations that can be effective regardless the region.

The aim of the article is to substantiate and describe the components of the universal model of knowledge management of TNCs, including the analysis of indicators and measurements of intellectual capital, definition and description of the components of the universal model of knowledge management of TNCs.

Materials and methods. The set of complementary methods of scientific research of economic processes and phenomena such as system-structural, comparative and statistical analysis have been used in the article. The information base of the research is statistical and analytical materials and information-analytical collections and reviews of international organizations; information materials of national and foreign research centers, scientific publications and statistical materials of leading TNCs.

Results. In the formation of the knowledge economy, TNCs can be considered as a dynamic institution that can influence the development of economic systems, both nationally and internationally, and which is in constant interaction with them through their own organizational, economic, technical, social levers. Actively influencing the international economic system, TNCs are forming new economic relations at both the national and global levels. It is important that the meaning of "world economy" concept is changing, it has been transformed from "international" to "transnational", and it is characterized by the establishment of more stable and long-term economic ties than before.

At the beginning of the XXI century it is expedient to take away the dominant role of transnationalization in the process of creating a new "geoeconomic map of the world" and growing economic interdependence of states where division by country is of secondary importance, giving way to division of economic forces and interests. Transnationalization, as an objectively determined process with multilevel and contradictory manifestations, significantly adjusts national and international development strategies and is therefore the most attractive object of a scientific research.

Knowledge management system is one of the important assets that unites databases, documents, policies, procedures, previously unexplored knowledge and experience of individual employees in TNC. This approach ensures sustainable socio-economic development and forms the competitiveness of TNC. In conditions of limited resources, the possibility of implementing the system knowledge management in an organization is its main competitive advantage. Therefore, technologies based on the knowledge system have become widespread and applied. The knowledge management system is a new stage in the development of management technology, replacing stage on the use of corporate databases [6]. 
The measurement of intellectual capital focuses on intangible assets in the context of strategic planning to determine their impact on value creation and benefits for organizations. It covers non-financial assets such as innovation opportunities, employee creativity or customer satisfaction and is future-oriented, namely the creation of value and core skills that provide a competitive advantage. From this point of view, the measurement of intellectual capital is necessary to test the capabilities of the organization in achieving strategic goals.

It is important to note that most existing ultrasound systems do not determine the indicators of intellectual capital, creating a gap between their measurements. According to Smith, this gap is one of the biggest shortcomings in the modern practice of measuring and managing the intellectual capital of TNCs.

The unified model of the dynamic organizational process of knowledge creation (SECI model), proposed by I. Nonaka and H. Takeuchi in 1991, was adopted as a basic theoretical model for understanding the dynamic essence of knowledge creation and effective management of this process. The SECI model characterizes the sequential movement of knowledge of individuals in an organization. This knowledge is transformed and amplified by the spiral of knowledge through processes such as socialization, externalization, combination and internalization. As part of the study, in order to systematize foreign experience and assess the possibilities of its use to identify the knowledge management system in MNC, three models of knowledge management - structural, matrix and process - were analyzed and the main tools that are used in these models were identified. The structural model The Knowledge Management Process Framework, Bukowitz and Williams (1999) focuses on knowledge discovery, knowledge use, learning and knowledge dissemination. The matrix model of the knowledge management Matrix, Gamble and Blackwell (2001) is based on determining the source of knowledge, organizing knowledge, assessing the strengths and weaknesses of the company's knowledge management system, determining the relevance of knowledge and the possibility of reuse, assimilation of knowledge in the process of use. Process model The Knowledge Management Process, Botha (2008) aims to develop and understand knowledge, organize and capture knowledge, share and disseminate knowledge [7].

In the formation of the knowledge economy, it is strategically necessary to create a model of knowledge management of TNCs, in which there would be a link between the UZ system and the measurement of intellectual capital, which would focus on supporting the measurement of TNC intellectual capital through knowledge management, demonstrating the contribution of these systems.

Models of measuring intellectual capital Intellectual capital (IC) refer to intangible assets that can bring future economic benefits, i.e. the value of creation. These assets are a key competitive advantage, they are characterized by invisibility, difficulties in quantification and acquisition without monetary nature and without physical substance. Its measurement 
reflects the added value of knowledge for organizations, allows you to monitor the performance of knowledge assets and related activities, provides an understanding of how organizations develop, manage and use their knowledge assets.

Table 1 summarizes the models for measuring intellectual capital, identifying the components specified in each of them.

Table 1

Measurements of intellectual capital

\begin{tabular}{|c|c|}
\hline Type of the capital & Index \\
\hline \multicolumn{2}{|c|}{ Human capital } \\
\hline \multicolumn{2}{|c|}{ Induvidual human capital } \\
\hline $\begin{array}{l}\text { Indicators of absenteeism } \\
\text { average level of IT literacy } \\
\text { years of work in companies }\end{array}$ & $\begin{array}{l}\text { Motivation index } \\
\text { digital literacy index } \\
\text { employee satisfaction index }\end{array}$ \\
\hline \multicolumn{2}{|c|}{ Human capital of the company } \\
\hline $\begin{array}{l}\% \text { full-time employees } \\
\% \text { of part-time employees } \\
\% \text { specialized employees }\end{array}$ & $\begin{array}{l}\text { Initiative index } \\
\text { innovation index } \\
\text { leadership index }\end{array}$ \\
\hline \multicolumn{2}{|c|}{ National human capital } \\
\hline $\begin{array}{l}\% \text { men, women } \\
\text { the average age of the employee } \\
\text { average level of literacy of employees } \\
\text { distribution by age groups }\end{array}$ & $\begin{array}{l}\text { Gender inequality index } \\
\text { loyalty index } \\
\text { employee engagement index } \\
\text { employee satisfaction index }\end{array}$ \\
\hline \multicolumn{2}{|c|}{ Structural capital } \\
\hline \multicolumn{2}{|c|}{ Consumer capital } \\
\hline $\begin{array}{l}\text { Information technology capabilities } \\
\text { administrative costs / employee } \\
\text { administrative costs / total receipts } \\
\text { quality of execution (ISO 9000) }\end{array}$ & $\begin{array}{l}\text { Profitability index } \\
\text { labor quality development index } \\
\text { process efficiency index } \\
\text { business reputation index }\end{array}$ \\
\hline \multicolumn{2}{|c|}{ Organizational capital } \\
\hline $\begin{array}{l}\text { The cost of developing new products or services } \\
\text { experienced staff / total staff } \\
\text { hours in development } \\
\text { hours of training }\end{array}$ & $\begin{array}{l}\text { Index of intellectual potential } \\
\text { human development index } \\
\text { labor quality index } \\
\text { freedom of education index }\end{array}$ \\
\hline \multicolumn{2}{|c|}{ Innovational capital } \\
\hline \multicolumn{2}{|c|}{ Innovative-technological } \\
\hline $\begin{array}{l}\text { Availability of information } \\
\text { innovative opportunities } \\
\text { innovative staff } \\
\text { investment in IT } \\
\text { investment in IT development }\end{array}$ & $\begin{array}{l}\text { ICT development index } \\
\text { innovation capacity index } \\
\text { global index of effective innovation } \\
\text { index of information opportunities } \\
\text { process efficiency index }\end{array}$ \\
\hline \multicolumn{2}{|c|}{ Creative } \\
\hline $\begin{array}{l}\text { Digitalization } \\
\text { talent } \\
\text { breakthrough technologies } \\
\text { investment in new competencies }\end{array}$ & $\begin{array}{l}\text { Digitalization index } \\
\text { talent competitiveness index } \\
\text { index of technological readiness } \\
\text { labor productivity index }\end{array}$ \\
\hline \multicolumn{2}{|c|}{ Capital of relationships } \\
\hline \multicolumn{2}{|c|}{ Capital of professionalism } \\
\hline $\begin{array}{l}\text { The average duration of the relationship } \\
\text { experienced staff / total staff }\end{array}$ & $\begin{array}{l}\text { Productivity index } \\
\text { education index }\end{array}$ \\
\hline \multicolumn{2}{|c|}{ Capital of brand } \\
\hline $\begin{array}{l}\text { Customer visits to the company } \\
\text { number of customers }\end{array}$ & $\begin{array}{l}\text { Customer satisfaction index } \\
\text { company image }\end{array}$ \\
\hline
\end{tabular}

Source: compiled by the author, based on [8].

40 
Models are characterized by various components: human, structural and relative capital, as well as social capital, $R \& D$, corporate identity, environmental capital or others, depending on the characteristics. At the same time, human, structural, innovative and capital relations are the components that are most often used in models.

Human capital (includes individual human capital, individual company capital and national human capital) is related to individual abilities, knowledge, skills, experience and problem-solving skills. It is manifested in the competence, attitude and intellectual dexterity of the employee. Competencies include skills and education, while attitudes cover employee behavior. Intellectual dexterity helps to find innovative solutions and change methods to solve the problem.

Structural capital (consumer capital, organizational capital) is related to systems, organizational processes, technologies, concepts and business models with databases, documents, patents, copyrights and other codified knowledge. According to Roos, structural capital is what stays with a company when employees go home overnight.

Innovative (innovative technological, creative) related to investment financing of innovation activities and the securities market of companies in high-tech industries; includes R\&D funding within the innovative technological process, venture capital, capital acquired through the placement of securities of enterprises in high-tech industries and long-term bank loans to expand the innovative activities of companies.

Relationship capital (professional capital, brand capital) is related to alliances and relationships with customers, partners, suppliers, investors and communities. This also includes brand awareness, organization image and market position. Relationship capital is built-in knowledge and added value from relationships with others.

The systematization of indicators proposed by each of the models of measuring intellectual capital was also done in order to determine a set of valuable indicators for measuring intangible assets.

The researchers have written about the use of different types of ultrasound system. The classifications mentioned by these authors are based on various assumptions: some of them are based on technological problems, some on related functionality; others still combine these two criteria in one classification. But, on the other hand, some of these classifications do not draw a clear line between the knowledge management system and tradetional information systems. The variety of classifications of the ultrasound system on the basis of different approaches leads us to systematize the categories of the ultrasound system according to their problems, capabilities and functional features. This systematization includes the following categories of knowledge management system:

- business intelligence systems;

- collaboration systems (group software);

- competency management systems;

- corporate portals;

ISSN 1727-9313. HERALD OF KNUTE. 2020. 
- document management systems;

- e-learning systems;

- expert systems;

- knowledge identification systems;

- knowledge maps;

- document management systems [9].

Table 2 summarizes the IR measurement models and identifies the components specified in each model. The systematization of the indicators proposed by each of the models of measuring intellectual capital was also done in order to review a certain set of values for measuring intangible assets. The models describe different components, such as human capital, structural capital, innovation capital and relationship capital, as well as social capital, corporate identity, environmental capital, etc., depending on their own characteristics.

Table 2

\section{Sources of quantitative assessment of intellectual capital in the context of knowledge management}

\begin{tabular}{|c|c|}
\hline Source & Quantitative assessment \\
\hline $\begin{array}{c}\text { System management } \\
\text { document }\end{array}$ & $\begin{array}{l}\text { Access to the knowledge base of the organization } \\
\text { Contribution to the knowledge base of the organization } \\
\text { Time (average) for the request } \\
\text { Knowledge level access / reuse }\end{array}$ \\
\hline $\begin{array}{l}\text { Maps of the } \\
\text { knowledge }\end{array}$ & $\begin{array}{l}\text { Access to the knowledge base of the organization } \\
\text { Contribution to the knowledge base of the organization } \\
\text { Time (average) for the request } \\
\text { Knowledge level access / reuse }\end{array}$ \\
\hline System cooperation & $\begin{array}{l}\text { Projects in cooperation with external organizations } \\
\text { Projects in collaboration with other working groups } \\
\text { Speed of dissemination of best practices } \\
\text { Questions reported on forums }\end{array}$ \\
\hline $\begin{array}{l}\text { Workflow } \\
\text { Systems }\end{array}$ & $\begin{array}{l}\text { Processes completed without errors } \\
\text { Processes according to manuals } \\
\text { Processes updated } \\
\% \text { of processes completed on time } \\
\% \text { of automated business processes }\end{array}$ \\
\hline $\begin{array}{l}\text { Business intelligence } \\
\text { system }\end{array}$ & $\begin{array}{l}\text { New business opportunities } \\
\text { Speed of investment in new markets } \\
\text { Market share in the segment } \\
\text { Geographical distribution of customers } \\
\% \text { of new customers / lost customers } \\
\text { Sales speed in new markets } \\
\text { Speed of sales to new customers } \\
\text { Customer satisfaction index } \\
\text { Employee satisfaction index }\end{array}$ \\
\hline Expert systems & $\begin{array}{l}\text { Specialists with a degree of specialization } \\
\text { Managers with a degree of specialization } \\
\text { Access to current issues } \\
\text { Expert contribution: best practices, tips, suggestions } \\
\text { Level of expertise access / reuse } \\
\% \text { of new experts }\end{array}$ \\
\hline
\end{tabular}

42 
End of the table 2

\begin{tabular}{|c|l|}
\hline Source & Quantitative assessment \\
& Average training time per employee (days per year) \\
& Cost per capita in educational programs \\
& Average year of service in the organization \\
Competence & The average age of employees \\
management & \% Of employees by group age \\
systems & Abemale and male employees \\
& Employee rotation speed \\
& Employee satisfaction index \\
& \% of employees with academic degrees \\
\hline \multirow{3}{*}{ E-learning } & E-learning programs \\
Systems & Hours spent in e-learning programs \\
& \% of employees who have successfully completed e-learning training programs \\
& Employees with specialization based on e-learning programs \\
\hline \multirow{5}{*}{ Knowledge of system } & New patents \\
& Patents in registration \\
& Average number of registered patents \\
& The level of knowledge that is reused in new contexts \\
& New ideas for updating products, services or processes \\
& New products, services or processes created by innovative processes \\
& Certified processes \\
\hline Corporate Portals & Speed of knowledge dissemination / application \\
\hline
\end{tabular}

Source: compiled by the author, based on [10].

Knowledge management system belongs to a class of information systems used to manage organizational knowledge, which are based on information technology and focused on supporting organizational processes of creation, storage and retrieval of knowledge, dissemination and application. The main purpose of the system is to create an environment that facilitates the creation and use of knowledge and communication, cooperation between organizations.

At the beginning of the XXI century, it should be noted that there are no significant differences in the industry or service orientation of a multinational corporation. The materials of this study will be used in a model developed to clarify the potential contribution of the knowledge management system to the measurement of intellectual capital.

A model for linking the measurement of knowledge management system and intellectual capital. The main purpose of the model proposed in our study is to combine the system of knowledge management and measurement of intellectual capital, which indicates the contribution of these systems to value creation in TNCs. The model can also facilitate the choice of knowledge management system depending on the needs of the organization, bringing the choice of knowledge management system in line with strategic goals and intangible assets that provide competitive advantages. This provides a comprehensive view of intangible assets, covering the strategic and operational perspectives of knowledge management.

Components of the model of measuring intellectual capital. The purpose of this component is to identify intangible assets that provide a competitive advantage and ensure the development of the core competency organization. It also contains a specification of the relevant metrics in order to measure these intangible assets.

ISSN 1727-9313. HERALD OF KNUTE. 2020. 
The components of the intellectual capital measurement model begin with defining a mission and corporate strategic goals that identify business drivers, critical success factors, and intangible assets that can create wealth for an organization. The purpose of linking intellectual capital to strategic goals is to ensure that the organization receives a competitive advantage from the use of intellectual capital and knowledge management system.

This component can be implemented using one of the considered measurements of the intellectual capital model, such as Skandia Navigator, Balanced Scorecard, Intangible, Assets Monitor, Intelect Model, etc. It is important to note that the model presented in this study does not depend on the model of measuring intellectual capital, in order to avoid diminishing its application.

Component of the knowledge management system. The purpose of this component is to provide a set of measures useful for quantifying intellectual capital (metrics are specified in the first component of the model). A knowledge management system can help improve intellectual capital by supporting and improving organizational knowledge processes that are critical to an organization. However, this can only be achieved if the knowledge management system focuses on intangible assets that bring value, additional and competitive benefits to organizations, in line with their strategic goals. From this point of view, a knowledge management system can contribute to a quantitative set of useful indicators for measuring IM using the knowledge recorded in these systems by measuring the components of knowledge management and management system. This component should also help determine the optimal categories of knowledge management system, according to the corporation, needs and strategies, as well as match the choice of knowledge management system with intangible assets that bring competitive advantage.

The structure is implemented through different categories of knowledge management system, according to their own characteristics and functionality in support of knowledge management processes, namely the creation of knowledge, storage, dissemination and application. This relationship is based on the assumption that the knowledge management system as a technological system focused on the management of organizational knowledge does not support the application of knowledge; and only people can apply for knowledge. However, a knowledge management system can contribute to the development of an environment that allows the use of knowledge and applications from the people of the organization.

Component of the system of measuring intellectual capital. The purpose of this component is to support IC measurement according to the model and metric selected in the first component. The system of measuring intellectual capital uses a set of measures provided by different categories of the knowledge management system to quantify these indicators of intellecttual capital. It can also use some of the measures provided by other sources that complement the measurement of intellectual capital, such as financial programs, quality systems, enterprise resource planning systems. This component establishes a link between the model of measuring intellectual capital and the knowledge management system, demonstrating the contribution 
of different categories of the knowledge management system to the intangible development of assets. The outcome of the intellectual capital measurement system consists of a report that facilitates the valuation of intangible assets and is the starting point for identifying strengths and weaknesses in terms of organizational knowledge development [1].

Valuation of intangible assets can facilitate the redefinition and reorganization of business drivers, success factors and intangible assets that create competitiveness in the organization.

Measures provided by the knowledge management system for the quantitative assessment of intellectual capital indicators. Each organization seeks to select the most appropriate indicators to measure the value of intangible assets and knowledge management initiatives according to their needs and strategic goals. A large number of indicators of intellectual capital can be quantified through the knowledge management system, i.e. through the knowledge recorded in the KMS. A significant number of knowledge management indicators from different categories and suppliers have been analyzed to clarify the potential contribution of these systems to the measurement of ICs.

Conclusion. One of the consequences of the growing importance of knowledge and organizational learning in economics has become knowledge management and at the same time it is a new management function and a special type of joint activity. At the beginning of the XXI century there is a dynamic change of epochs of world socio-cultural development to a new epoch of knowledge and creativity. Nevertheless, it can be argued that this kind of conflict situation in the world occurs due to the existence of several epochs simultaneously, i.e. currently the process of formation of post-industrial (information-innovation) society, although the era of the new economy at the present stage is presented in a new content, where the knowledge resource reaches a qualitatively new level. Based on the results of the study, it is shown that the existing models of knowledge management do not fully analyze the components of knowledge management models. That is why this article analyzes the dimensions of intellectual capital, on the basis of which the components of the universal model are developed.

\section{REFERENCES}

1. Nonaka, I., \& Takeuchi, H. (2013). Kompanija - sozdatel' znanija. Zarozhdenie i razvitie innovacij v japonskih firmah [The Knowledge-Creating Company: How Japanese Companies Create the Dynamics of Innovation]. (Trans). Moscow: ZAO "Olimp Biznes" [in Russian].

2. Mil'ner, B. Z. (2017). Upravlenie znanijami: pervye itogi, uroki i perspektivy [Knowledge management: first results, lessons and perspectives]. Problemy teorii $i$ praktiki upravlenija - Problems of theory and practice of management, 6, 37-46 [in Russian].

3. Gavrilova, T. A., \& Horoshevskij, V. F. (2018). Bazy znanij intellektual'nyh sistem [Knowledge bases of intelligent systems]. SPb.: Piter [in Russian].

4. Popov, E. V., Vlasov, M. V., Gurina, K. O. (2018). Formirovanie institutov upravlenija znanijami [Formation of knowledge management institutions]. Innovacii Innovation, 5, 96-99 [in Russian].

ISSN 1727-9313. HERALD OF KNUTE. 2020. № 
5. Tiwana, A. (2016). The knowledge management toolkit: practical techniques for building a knowledge management system. Prentice Hall PTR Upper Saddle River, NJ, USA [in English].

6. Armstrong, Charles Allan, \& Krebs, Valdis Edgars (2002). Knowledge management system. Patents. Retrieved from https://www.google.com/patents/ US20020169737 [in English].

7. The KNOW Network. Retrieved from http://www.knowledgebusiness.com/ knowledgebusiness/ templates/home.aspx?siteId=1\&menuItemId=25 [in English].

8. Dolk, D., \& Konsynski, B. (2019). Knowledge Representation for Model Management Systems. IEEETransactions on Software Engineering, 619-628 [in English].

9. Masuda, Y. (2010). The informational Society as Post-Indastrial Society. Worldfuture Society, 171 [in English].

10. Komarova, A. V. (2017). Strategicheskie aspekty upravlenija znanijami v transnacional'nyh korporacijah [Strategic aspects of knowledge management in transnational corporations]. Rossijskij vneshnejekonomicheskij vestnik - Russian Foreign Economic Bulletin, 4. 17-26 [in Russian].

The article submitted to editor's office on 24.10.2020.

Бусарєва Т. Універсальна модель управління знаннями у корпорації.

Постановка проблеми. У різних галузях економіки ступінь впливу певних елементів інтелектуального капіталу на результати діяльності ТНК буде різним, оскільки навіть на розвинених ринках інтелектуальний капітал може відігравати різну роль у діяльності корпорацій. Саме тому при розвитку економіки знань необхідною умовою розвитку ТНК є обтрунтування складових універсальної моделі управління знаннями.

Аналіз останніх досліджень та публікацій показав, щзо, незважаючи на певний науковий прогрес, питання щодо компонентів універсальної моделі ТНК залитається невиріменим.

Метою дослідження є обтрунтування та опис компонентів універсальної моделі управління знаннями ТНК, включаючи аналіз показників та вимірювань інтелектуального капіталу, визначення та опис компонентів універсальної моделі управління знаннями ТНК.

Матеріали та методи. Для досягнення мети використано набір додаткових методів наукового дослідження економічних процесів та явищ: системно-структурний, порівняльний та статистичний аналіз.

Результати дослідження. Система управління знаннями є одним із важливих активів ТНК, щуо об'єднує бази даних, документи, політику, прочедури, раніме не вивчені знання та досвід окремих працівників. Такий підхід забезпечує стійкий соціально-економічний розвиток та формує конкурентоспроможність ТНК. В умовах обмеженості ресурсів можливість впровадження системного управління знаннями в корпоращії є ї̈ основною конкурентною перевагою. Тому технології, засновані на системі знань, набули широкого поширення та застосування. Система управління знаннями - це новий етап у розвитку технології управління, що замінює етап використання корпоративних баз даних.

Висновки. На початку XXI cm. відбувається динамічна зміна епох світового соціокультурного розвитку на нову епоху знань та творчості. У той же час такий тип конфліктної ситуації у світі виникає внаслідок існування декількох епох одночасно, тобто нині відбувається формування постіндустріального (інформаційноінноваційного) суспільства, де ресурс знань виходить на якісно новий рівень.

Ключові слова: економіка знань, ТНК, управління знаннями, управління ресурсами, НДДКР, модель управління знаннями. 